\title{
Rare Plant Preservation through Village Forest Policy in Bali
}

\author{
Nyoman Wijana ${ }^{1}$, I Gusti Agung Nyoman Setiawan ${ }^{2}$ \\ ${ }^{1,2}$ Department of Biology Education \\ Universitas Pendidikan Ganesha \\ Singaraja, Indonesia
}

\begin{abstract}
Traditional villages in Bali has its authorities to rule the village, including how to manage the village forest. While the aim of the management of the village forest has been mainly for ceremonial requirements, it has contributed to the preservation of several rare plants in Bali. The present study aimed at mapping rare plant species distribution in the village forest of Penglipuran Village, Bangli, Bali and how the management of the village forest affects the distribution of rare plants in the village forest. The study revealed that there were 21 families with 34 species of plants in the village forest, with 17 of the species that are categorized as rare plants distributed in narrow, medium and wide in the forest area in clump distribution pattern. It was also revealed that some of the rare plants were preserved because of their roles in the traditional and religious ceremony.
\end{abstract}

Keywords-Mapping, Rare Plants, Village Forest, Penglipuran Village

\section{INTRODUCTION}

Based on the 2010 Bali Forestry Departement data, Bali's land forest area is $127,721.01$ hectare or only 22.59 percentof Bali island total area which is 563,286 hectare. In addition to natural disasters of droughts, floods and landslides, forest destruction due to human intervention, will also cause the extinction of plant species, including the local plants which have important meaning and significance for the local community, for the education and research, as well as for the national and worldwide interests as the sources of germplasm.

Some studies, such as studies done by $[1][2][3][4][5][6][7][8][9][10][11][12]$ respectively in the buffer forests of Lake Batur (Bangli) Buyan Lake (Buleleng), Tenganan Pegringsingan Village (Karangasem), village forests of Penglipuran (Bangli), Tigawasa Village and Cempaga Village (Buleleng), and the vegetation of Lovina beach (Buleleng), indicate that species diversity at those study sites generally showed a low to moderate species diversity index and none of those studies showed high diversity index. This means that there are some certain species that can be categorized as rare plants in terms of limited density, endemic distribution and low frequency. Studies of terrestrial vegetation outside Bali done by $[13][14][15][16][17][18][19][20]$ examined the species composition, species diversity and formal legal forest management. In general, the result of those studies was the composition of plants in each study site, in which those species composition were arranged in form of floristic list.
From the studies mentioned above, there was no in depth study of rare plant species and the spreading map of those rare species that survive in their original environment, in this case the rare plant species in the village forest of Penglipuran, Bangli, Bali. Meanwhile, rare plant species that still survive in the site are hardly found, their distribution spots are unknown, and so are their distribution patterns.

In a biology field study, it is very essential to know the name of the organism especially the name of the plants growing in the area of the study. In the meantime, biological field study meets a lot of obstacles in the identification of organism names. The results of this study could be used as a learning media in identifying the scientific name of a plant and its existence in the natural environment.

Based on the above description, depth study of rare plant species distribution map and the patterns in the site is done in this research. This study did not impact locally, but also regionally, nationally and even globally, such as in reducing global warming, climate changes, and in increasing green ecology, green economic as well as saving germplasm. In the future this study is able to bring the rare plant species destination in their natural site. The objects of this research are to produce a map of rare plant species distribution the village forest of Penglipuran, Bangli, Bali; to acknowledge the distribution pattern of those rare plant species; and the implication as a learning media.

\section{METHOD}

\section{A. Research Population and Sampling}

This research population included mapping area and rare plant species. The research samples were the mapping areas taken from all forest border and the rare plant species were rare plants covered in the square. Simple measurement technique was used as the mapping technique [21]. The sampling technique for rare plant species was systematic sampling.

\section{B. Rare Plant Species Distribution Mapping}

This research used mapping methods of simple measurement refers to [21] on simple mapping map and boundary note. Simple mapping steps are described as follows:

1. Conduct temporary pointing by determining benchmark points. 


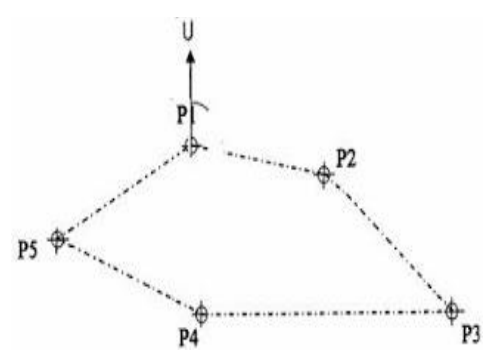

Fig. 1. Benchmark Points

2. Conduct a distance measurement directly through the distance between the wooden stakes using a long gauge equipped with lines and number of meters. The gauge is placed horizontally when measuring the distance so that it is measured precisely.

3. Conduct a ground surface level differences calculation with a heeling on each wooden stakes distances.

4. Perform a simple definitive measurement with sliding system compass polygon method refers to [22].

a. Conduct an angle measurement or azimuth on each wooden stakes placed at the location points to form a closed polygon.

b. Calculate the coordinates of compass polygon point by knowing the starting and ending point coordinates, and then determine the geographic azimuth.

Study site can be seen on Figure 2.

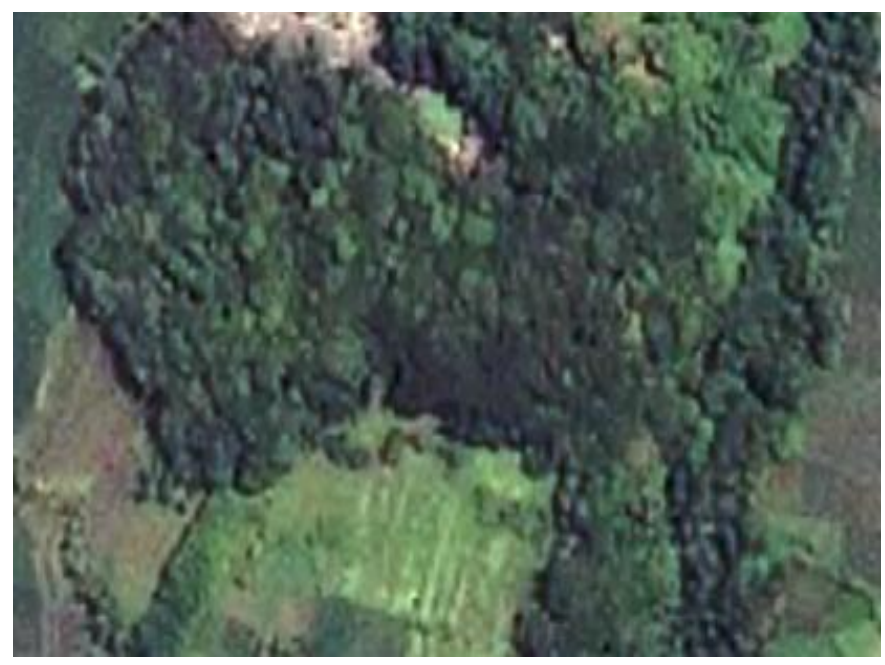

Fig.2. Penglipuran Village Forest Area. (Source: Google Earth, 2017)

\section{Rare Plant Species Distribution Area}

Plot (quadratic) positioning on the forest area with the size of $20 \times 20$ meters at the transect line which were placed alternately and continuously on left and right of 100 squares. Between one square to another was given 10 meter distance. Then, notes and documentations from the observation were taken.
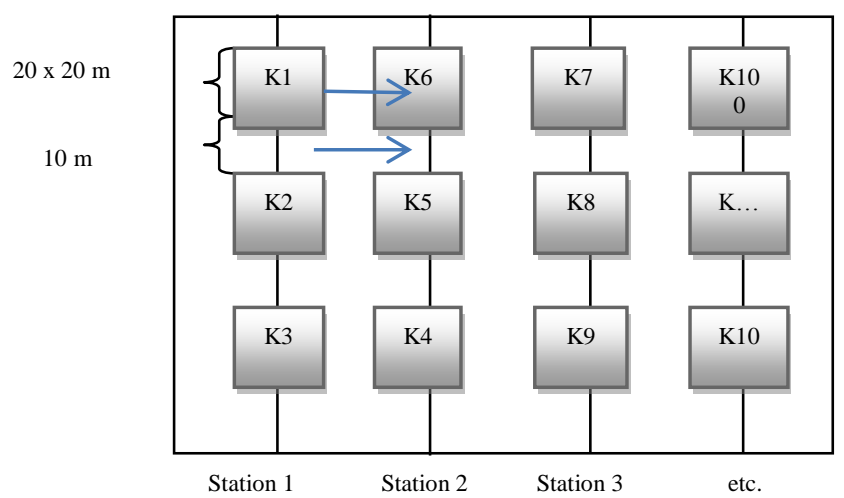

Fig.3. Layout of Quadratic Positioning

Observation results are loaded up to the work table below.

TABLE 1. OBSERVATION RESULTS OF DISTRIBUTION PATTERN

\begin{tabular}{cccccc} 
No. & $\begin{array}{c}\text { Coordinate } \\
\text { Plot }\end{array}$ & $\begin{array}{c}\text { Number of } \\
\text { Individuals }\end{array}$ & $\begin{array}{c}\text { No. } \\
\text { Plot }\end{array}$ & $\begin{array}{c}\text { Coordinate } \\
(\mathbf{X}, \mathbf{Y})\end{array}$ & $\begin{array}{c}\text { Number } \\
\text { of } \\
\text { Individual }\end{array}$ \\
\hline $\mathbf{1}$ & & & 90 & & \\
$\mathbf{2}$ & & & $\ldots$ & & \\
$\mathbf{3}$ & & & 100 & & \\
\hline
\end{tabular}

\begin{tabular}{cccccccc}
\multicolumn{1}{c}{ TABLE } & 2. & SPECIES DISTRIBUTION DENSITY RECAP & \\
\hline $\begin{array}{c}\text { Number of } \\
\text { Individuals }\end{array}$ & $\mathbf{0}$ & $\mathbf{1}$ & $\mathbf{2}$ & $\mathbf{3}$ & $\mathbf{4}$ & $\mathbf{5}$ & Total \\
\hline $\begin{array}{c}\text { Number of } \\
\text { Plots }\end{array}$ & $\ldots \ldots$ & $\ldots \ldots$ & $\ldots \ldots$ & $\ldots \ldots$ & $\ldots \ldots$ & $\ldots \ldots$ & 100 \\
\hline
\end{tabular}

D. Data Analysis Techniques

1. Data analysis on distribution map of rare plant species was done descriptively.

2. Data analysis on distribution pattern of rare plant species was done using Poison ecology statistic by the formula: [23][24][25][10].

$$
\mathrm{X}^{2}=\frac{(\text { observed-Expected }) 2}{\text { Expected }}
$$

If the $X^{2}$ value $>X^{2}$ table, then the plant species are nonrandomly distributed. If $\mathrm{X}^{2}$ value $<\mathrm{X}^{2}$ table, then the plant species are randomly distributed. Furthermore, if the plant species are non-randomly distributed, then continue to the variance test. If the variance test result is $v / x \geq 1$ then the plant species distributed in clump/group, and if it shows $\mathrm{v} / \mathrm{x}<1$ then the plant species regularly distributed.

\section{RESEARCH RESULTS AND DISCUSSION}

\section{A. Research Results}

1. Data analysis on distribution map of rare plant species was done descriptively.

The rare plant species composition in the village forest of Penglipuran, Bangli, Bali, presented in Table 3. 
Table 3. General Floristic Plant Lists In The Village Forest Of Penglipuran, Bangli, Bali

\begin{tabular}{|c|c|c|c|c|c|c|}
\hline \multirow[b]{2}{*}{ No } & \multirow[b]{2}{*}{ Family } & \multicolumn{2}{|c|}{ Plant Species Name } & \multirow{2}{*}{ Total } & \multirow{2}{*}{ Density } & \multirow[b]{2}{*}{ Relative Density } \\
\hline & & $\begin{array}{c}\text { Local/ Indonesian } \\
\text { Name }\end{array}$ & Scientific Name & & & \\
\hline 1 & Zingiberaceae & Ilak & Aтотитsp & 3 & 0,00032967 & 0,89 \\
\hline \multirow{3}{*}{2} & \multirow{3}{*}{ Sapotaceae } & Bala & Mimusopssp & 11 & 0,001208791 & 3,26 \\
\hline & & Balabuah & Mimusopselengi & 16 & 0,001758242 & 4,75 \\
\hline & & Nyaman & Manilkarasp & 5 & 0,000549451 & 1,48 \\
\hline 3 & Dipterocarpaceae & Balau & Hopeacelebica & 1 & 0,00010989 & 0,30 \\
\hline \multirow{2}{*}{4} & \multirow[t]{2}{*}{ Magnoliaceae } & Base-base & Elmerilliaovalis & 28 & 0,003076923 & 7,73 \\
\hline & & Cempaka & Michelia alba & 4 & 0,00043956 & 1,19 \\
\hline \multirow[t]{2}{*}{5} & \multirow[t]{2}{*}{ Anacardiaceae } & Bejaran & Lanneacoromandelica & 5 & 0,000549451 & 1,48 \\
\hline & & Book & Dracontomelonsp & 4 & 0,00043956 & 1,19 \\
\hline 6 & Rutaceae & Bila & Aeglemarmelos & 18 & 0,001978022 & 4,97 \\
\hline 7 & Annonaceae & Blekatak & Polyalthialateriflora & 11 & 0,001208791 & 3,26 \\
\hline 8 & Fagaceae & Bleket & Lithocarpuscelebicus & 2 & 0,00021978 & 0,59 \\
\hline 9 & Euphorbiaceae & Boni & Antidesmabonius & 2 & 0,00021978 & 0,59 \\
\hline \multirow{2}{*}{10} & \multirow[t]{2}{*}{ Myrtaceae } & Daunsalam & Syzygiumpolyanthum & 8 & 0,000879121 & 2,37 \\
\hline & & Juwetbatu & Syzygiumcumini & 9 & 0,000989011 & 2,67 \\
\hline 11 & Elaeocarpaceae & Genitri & Elaeocarpusganitrus & 5 & 0,000549451 & 1,48 \\
\hline \multirow{3}{*}{12} & \multirow[t]{3}{*}{ Meliaceae } & Langsat & Lansiumsp & 39 & 0,004285714 & 11,57 \\
\hline & & Majegau & Dysoxylumdensiflorum & 2 & 0,00021978 & 0,59 \\
\hline & & Gau-gau & Dysoxylum sp & 137 & 0,015054945 & 37,85 \\
\hline 13 & Oxalidaceae & Kacret & Sarcothecacelebica & 1 & 0,00010989 & 0,30 \\
\hline \multirow{2}{*}{14} & \multirow{2}{*}{ Myristicaceae } & Kayujelema & Knemalaurina & 1 & 0,00010989 & 0,30 \\
\hline & & Pala jiwa & Myristicasp & 9 & 0,000989011 & 2,67 \\
\hline 15 & Ulmaceae & Kenongnang & Gironnierasubaequalis & 9 & 0,000989011 & 2,67 \\
\hline 16 & Phyllanthaceae & Kepundung & Baccaurearacemosa & 1 & 0,00010989 & 0,30 \\
\hline \multirow{5}{*}{17} & \multirow{5}{*}{ Moraceae } & Mabi & Ficusrasemosa & 1 & 0,00010989 & 0,30 \\
\hline & & Nangka & Artocarpusheterophyllus & 5 & 0,000549451 & 1,48 \\
\hline & & Nangka-nangka & Artocarpussp & 1 & 0,00010989 & 0,30 \\
\hline & & Tehep & Artocarpuselastica & 3 & 0,00032967 & 0,89 \\
\hline & & Beringin & Ficusbenjamina & 1 & 0,00010989 & 0,30 \\
\hline 18 & Gnetaceae & Melinjo & Gnetumgnemon & 6 & 0,000659341 & 1,78 \\
\hline \multirow{2}{*}{19} & \multirow{2}{*}{ Clusiaceae } & Mundeh & Garciniadulcis & 2 & 0,00021978 & 0,59 \\
\hline & & Pradah & Garciniacerlebica & 1 & 0,00010989 & 0,30 \\
\hline 20 & Sterculiaceae & Pongpongan & Heritieralittoralis & 3 & 0,00032967 & 0,89 \\
\hline 21 & Leguminosae & Telan & Cynometraramiflora & 8 & 0,000879121 & 2,37 \\
\hline \multicolumn{4}{|c|}{ Total } & 362 & 0,03978022 & 100,00 \\
\hline
\end{tabular}

There were 34 plant species found in the village forest of Penglipuran which were categorized into 21 families, they were: 3 species of Meliaceae with the highest number of individual species as many as 178 individual species, meanwhile plants from Dipterocarpaceae, Oxalidaceae, Phyllanthaceae had the lowest species number which was 1 species with 1 individual species each. Fagaceae ( 2 individual species), Euphorbiaceae (2 individual species), Zingiberaceae (3 individual species), Sterculiaceae (3 individual species), Clusiaceae (3 individual species), Elaeocarpaceae (5 individual species), Gnetaceae (6 individual species), Leguminosae (8 individual species), Anacardiaceae (9 individual species), Ulmaceae (9 individual species), Myristicaceae (10 individual species), Annonaceae (11 individual species), Moraceae (11 individual species), Myrtaceae (17 individual species), Rutaceae (18 individual species), Sapotaceae (32 individual species), and Magnoliaceae (32 individual species).

From the Table 4 above, then the plant species were identified to categorize them as rare category. The identification results are shown in Table 4. 
TABLE 4. THE LISTS OF RARE PLANT SPECIES IN THE VILLAGE FOREST OF PENGLIPURAN

\begin{tabular}{|c|c|c|c|c|}
\hline \multirow[t]{2}{*}{ No } & \multirow[t]{2}{*}{ Family } & \multicolumn{2}{|c|}{ Plant Species Name } & \multirow[t]{2}{*}{ Status of Rarity } \\
\hline & & Local/Indonesian Name & Scientific Name & \\
\hline \multirow[t]{2}{*}{1} & \multirow[t]{2}{*}{ Magnoliaceae } & Base-base & Elmerilliaovalis & L.Kab \\
\hline & & Cempaka & Michelia alba & L.Kab \\
\hline 2 & Anacardiaceae & Bejaran & Lanneacoromandelica & L.Kab \\
\hline 3 & Rutaceae & Bila & Aeglemarmelos & LB \\
\hline 4 & Euphorbiaceae & Boni & Antidesmabonius & LB \\
\hline 5 & Elaeocarpaceae & Genitri & Elaeocarpusganitrus & L.Kab \\
\hline 6 & Myrtaceae & Juwetbatu & Syzygiumcumini & LB \\
\hline \multirow[t]{2}{*}{7} & \multirow[t]{2}{*}{ Myristicaceae } & Kayujelema & Knemalaurina & L.Kab \\
\hline & & Pala jiwa & Myristicasp & LN \\
\hline 8 & Phyllanthaceae & Kepundung & Baccaurearacemosa & L.Kab \\
\hline \multirow[t]{3}{*}{9} & \multirow[t]{3}{*}{ Moraceae } & Mabi & Ficusrasemosa & L.Kab \\
\hline & & Nangka-nangka & Artocarpussp & LB \\
\hline & & Beringin & Ficusbenjamina & L.Kab \\
\hline 10 & Meliaceae & Majegau & Dysoxylumdensiflorum & LB \\
\hline 11 & Clusiaceae & Mundeh & Garciniadulcis & LB \\
\hline 12 & $\underline{\text { Sapotaceae }}$ & Nyaman & Manilkarasp & LB \\
\hline 13 & Clusiaceae & Peredah & Garciniacerlebica & L.Kab \\
\hline
\end{tabular}

Information:

LB: Bali-level Rarity

L.Kab: District of Bangli-level Rarity

LN: National-level Rarity

*): Local Names using Balinese language

From those 34 species in Village Forest of Penglipuran, 17 of them or $50 \%$ of them were categorized as rare plants. The category identification the plant species was based on the interview with the local community, the forestry services, and various study references. Based on the status of rarity, it can be divided into District-level rarity, Province of Bali-level rarity, and National-level rarity.

\section{The Mapping of Rare Plants Species}

The mapping results of rare plants species in village forest of Penglipuran showed in Figure 4. From the Figure 4 shows that there were 17 distributions of rare plants species found in the area of Penglipuran Village. The rare plant species on the distribution map were distinguished by color for each species. The purpose of this color distinction was to make it easier to see the distribution on the map. Based on the 17 rare plant species distributions, it was known that base-base species (Elmerilliaovalis) had the widest distribution of $40 \%$, then bila (Aeglemarmelos) of 30\%, juwetbatu (Syzygiumcumini) and palajiwa (Myristicasp) (20\%), Bejaran (Lanneacoromandelica), Cempaka (Michelia alba), Genitri (Elaeocarpusganitrus), Nyaman (Manilkarasp) (10\%). Furthermore, Boni (Antidesmabonius), Kayujelema (Knemalaurina), Kepundung (Baccaurearacemosa), Mabi (Ficusrasemosa), Majegau (Dysoxylumdensiflorum), Mundeh (Garciniadulcis), Nangka-nangka (Artocarpussp), Pradah (Garciniacerlebica), Beringin (Moraceae) had 5\% distribution.

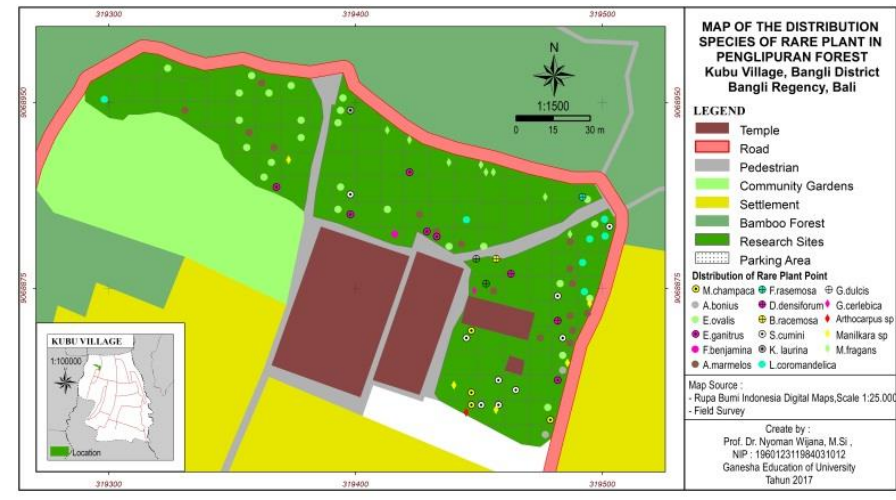

Fig.4. The Mapping of Rare Plant Species Distrbution in The Village Forest of Penglipuran, Bangli, Bali

3. The Distribution Pattern of Rare Plant Species

The analysis results on the distribution pattern of rare plant species in the village forest of Penglipuran are shown in Table 5. 
TABLE 5. THE DISTRIBUTION PATTERNS OF RARE PLANT SPECIES IN THE VILLAGE FOREST OF PENGLIPURAN, BANGLI.

\begin{tabular}{clc}
\hline No & \multicolumn{1}{c}{ Rare Plant Name } & $\begin{array}{c}\text { Type of } \\
\text { Distribution Pattern }\end{array}$ \\
\hline 1 & Bila (Aeglemarmelos) & Clump/Group \\
\hline 2 & Base-Base (Elmerilliaovalis) & Clump/Group \\
\hline 3 & Bejaran (Lannea coromandelica) & Clump/Group \\
\hline 4 & Juwet Batu (Syzygium cumini) & Clump/Group \\
\hline 5 & Boni(Antidesma bonius) & Clump/Group \\
\hline 6 & Cempaka (Michelia alba) & Clump/Group \\
\hline 7 & Gentri (Elaeocarpus ganitrus) & Clump/Group \\
\hline 8 & Kayu Jelama (Knema laurina) & Clump/Group \\
\hline 9 & Kepundung (Baccaurea racemosa) & Clump/Group \\
\hline 10 & Mabi (Ficus rasemosa) & Clump/Group \\
\hline 11 & Majegau (Dysoxylum densiflorum) & Clump/Group \\
\hline 12 & Mundeh (Garcinia dulcis) & Clump/Group \\
\hline 13 & Nyaman (Manilkara sp.) & Clump/Group \\
\hline 14 & Palajiwa (Myristica fragans) & Clump/Group \\
\hline 15 & Nangka-nangka (Artocarpus sp.) & Clump/Group \\
\hline 16 & Predah (Garcinia cerlebica) & Clump/Group \\
\hline 17 & Beringin (Ficusbenjamina.) & Clump/Group \\
\hline
\end{tabular}

Based on the Table 5 above, it can be seen that the distribution pattern type of rare plant species in the village forest of Penglipuran, Bangli was group/clump distribution type.

\subsubsection{The Implication as a Biology Learning Media}

In an experiment on rare plant field identification, involving a class of students of Biology Department, Faculty of Math and Science, Universitas Pendidikan Ganesha, Singaraja-Bali, with total of 24 students, it showed that there were 15 rare plants $(89 \%)$ out of 17 rare plants in their natural environment had been known by the students, whereas two species of those rare plants $(11 \%)$ could not be identified by the students.

\section{B. Discussion}

17 species (50\%) out of 34 plant species found in the village forest of Penglipuran were categorized as rare plant species. The factors of those species rarity were: (1) The plants which were categorized as rare were considered as "sacred wood" by the community, which were mostly used for holy buildings (Hindu's prayer places in Bali) or for religious ceremony purposes (Hindu), re-cultivating and replanting were not undertaken by the community to replace the plants that had been cut down; (2) The rare plants reproduced so slowly that the community were not interested to cultivate them. Therefore, the rare plants only reproduced and survived naturally; (3) The interview with the village chief revealed that there had been an effort to cultivate the rare plants both by the forest management and the community. However, this effort was not completed with plant care treatment which caused discontinuance of the effort; (4) The interview results also revealed that the community had a concept called "Hutan Due", which made the people scared to get into the forest to do rare plants conservation. This "Hutan Due" concept meant that the community considered the forest as a sacred place. (5) There is also a belief that the forest products can be used for yadnya purpose only on ceremonies held in the village temples. If any person takes forest products for personal use, without having permission from the village authorities, charges can be pressed against that person in accordance with awig-awig or the village's traditional house rules [12].

The distribution of rare plant species is influenced by two main factors, they are the environment (external) and the plants ability to reproduce (internal). As stated by [26] that the limit of plants distribution is influenced by external factor, which is the habitat of the plant environment and internal factor, which is the reproduction ability. Based on the data, the distribution of rare plant species in the village forest of Penglipuran is divided into 4 factors, namely environmental climate factor (climatic), environmental edification, environmental biotic factor, and human intervention factor. The rare plant species in the village forest of Penglipuran are categorized as seed plants (spermatophyta), especially closed seed plants (angiospermae). Rare plant species multiply themselves naturally or generatively using their seeds. Their seeds are carried away by the wind or by the animals so that they have wide distribution area, not only near the area of the source plant. Moreover, the period of their flower blooming and fruit bearing is relatively long, therefore their reproduction ability is very rapid. Meanwhile, the other plant species which distribution area is narrow or only on particular areas are mostly plant species that has shorter flowering and fruiting period so that their ability to multiply or to grow is very slow.

The group type of distribution pattern is caused by the plants' seed reproduction method. Therefore, the seeds grow next to the source plant and this situation continues constantly and causes those rare plant species have a distribution pattern in group type. This is in accordance with a theory proposed by [10] about the supporting factors of group type distribution pattern, which is explained as follows. Seeds or fruits from plants that produce seeds tend to fall near the source plant. And then, due to the micro-reasons, the habitat is homogenous at macro level environment, however on lesser level the habitat consists of many different macrocytes that allow placement and stabilization of a species with different success rates. The most suitable macrocytes to a species tends to be denser occupied with the same species.

The implication of this study results in terms of biology field study indicated that there was 15 rare plant species $(89 \%)$ which could be identified and 2 rare plant species $(11 \%)$ unidentified. This was due to the limitations of GPS used by the students so that the students could not identify the location of the rare plant species they looked for; the plant images used to identify the rare plant species were imperfect or bad, they required improvement; and the rare plant species descriptions used by the students to look for the plants in the field, were incomplete and required further improvement.

\section{CONCLUSIONS AND RECOMMENDATIONS}

Thus, it can be concluded that plant species composition in the village forest of Penglipuran consisted of 21 families with 34 species; 17 out of 34 species were categorized as rare 
plants; the mapping results showed that the distribution of rare plant species were narrow, medium, and wide distribution in the forest area; and the distribution pattern was categorized as group distribution pattern. Here are some recommendations submitted, including, first, the forest management based on the local wisdom is important to be maintained so that the plant species do not become extinct; second, by the mapping of rare plant species in the village forest of Penglipuran, it can be developed as a new destination to introduce rare plant species in their original nature.

\section{REFERENCES}

[1] N. Wijana and I. N. Sumardika, "Penentuan Kualitas Air Danau Batur (Kajiandari Sisi ABC Envirotment)," 2004.

[2] N. Wijana and I. N. Sumardika, "Analsis Vegetasi Hutan Bukit Kangin Desa Adat Tenganan Pengringsingan, Kabupaten Karangasem," 2005.

[3] N. Wijana, M. Sutajaya, and N. Kariasa, "Analisis Kualitas Air, Aspek Kesehatan Masyarakat, Vegetasi Penyangga dan Upaya Pengelolaanoleh Masyarakat Seputar Danau Batur Kecamatan Kintamani Kabupaten Bangli,” 2006.

[4] N. Wijana, "Keanekaragaman Spesies Tumbuhan, Manfaat dan Upaya Pelestarian oleh Masyarakat Desa Adat Tenganan Pegringsingan, Karangasem," J. Wahana Mat. dan Sains., vol. 5, pp. $17-34,2008$

[5] N. Wijana and I. N. Sumardika, Pelestarian Jenis-JenisTumbuhan Berguna Melalui KearifanLokal di Desa Adat Tenganan Pegringsingan, Kabupaten Karangasem, Bali. Konservasi Flora Indonesia dalam Mengatasi Dampak Pemanasan Global Kebun Raya "EkaKarya- LIPI," 2009.

[6] N. Wijana, I. B. J. Swasta, and I. N. Sumardika, "Analisis ABC Environment pada Ekosistem Tumpang Tindih (Overlap Ecosystem) dalam Kaitannya dengan Penurunan Kualitas Air, Eutrofikasi, dan Rencana Pemantauan Lingkungan (RPL) Danau Buyan Kecamatan Sukasada Kabupaten Buleleng," 2010.

[7] N. Wijana, "Analisis Dampak Lingkungan Dan Upaya Pengelolaan Berbasis Ergologi Kawasan Wisata Lovina, Buleleng - Bali,” 2012.

[8] N. Wijana, "Analisis Vegetasi Hutan Adat, Upaya Pengelolaan Berbasis Kearifan Lokaldan Pemberdayaan Masyarakat Melalui Pendekatan Ergologi di Desa Bali Aga Buleleng-Bali," 2013.

[9] N. Wijana, "Analisis Komposisi dan Keanekaragaman Spesies Tumbuhan di Hutan Desa Bali AgaTigawasa, Buleleng - Bali,” J. Sains dan Hum., vol. 1, pp. 55-65, 2014.

[10] N. Wijana, Metode Analisis Vegetasi. Yogyakarta: Graha Ilmu, 2014.

[11] N. Wijana, "Analisis Dampak Lingkungan Terhadap Aktivitas Pembudidayaan Udang dengan Sistem Kurungan di Laut Lepas Desa Sangsit Kecamatan Sawan, Kabupaten Buleleng, Bali,” 2015.

[12] N. Wijana, Pengelolaan Lingkungan Hidup (Aspek Kearifan Lokal, Ergonomi, Ergologi, dan Regulasi). Singaraja: Undiksha Press, 2016.

[13] Arrijani, D. Setiadi, E. Guhardja, and I. Qayim, "Analisis Vegetasi Hulu DAS Cianjur Taman Nasional Gunung Gede-Pangrango," Biodiversitas, vol. 7, pp. 147-153, 2006.

[14] Irwanto, "Analisis Vegetasi untuk Pengelolaan Kawasan Hutan Lindung Pulau Marsegu, Kabupaten Seram Barat, Provinsi Maluku," Gajah Mada University, 2007.

[15] Junaedi, D. Indrawana, and Z. Mutaqien, "Diversity of Tree Communities in Mount Patuha Region, West Java," Biodiversitas, vol. 11, pp. 75-81, 2010.

[16] S. Hartini, "Keragaman Flora dari Monumen Alam Kersik Luway Kalimantan Timur," J. Biodiversitas, vol. 8, pp. 67-72, 2007.

[17] Onrizal, "Perubahan Tutupan Hutan Mangrove di Pantai Timur Sumatera Utara Periode 1977 - 2006," J. Biol. Indones., vol. 6, pp. 163-172, 2010

[18] Onrizal, C. Kusmono, B. H. Saharjo, I. P. Handayani, and T. Koto, "Analisis Vegetasi Hutan Hujan Tropika Dataran Rendah Sekunder di Taman Nasional Danau Sentarum, Kalimantan Barat," J. Biol., vol. 4, pp. 359-371, 2006.
[19] Purwaningsih, "Analisis Vegetasi Hutan pada Beberapa Ketinggian Tempat di Bukit Wawouwai, Pulau Wawonii Sulawesi Tenggara," $J$. Biodiversitas, vol. 7, pp. 49-53, 2006.

[20] Purwaningsih and R. Yusuf, "Analisis Vegetasi Hutan Pegunungan di Taman Nasional Gunung Ciremai, Majalengka, Jawa Barat," J. Biol. Indones., pp. 385-399, 2008.

[21] R. . Soenaryanto, Catatan Pemetaan Sederhana Petadan Tata Batas. Bogor: Pusat Pendidikan dan Latihan Kehutanan, 1976.

[22] E. Teten, Darjo, and U. S., Polygon Kompas. Kadipaten: Pelatihan Pengukuran Terrestris. Balai Latihan Kehutanan, 1999.

[23] G. W. Cox, Laboratory Manual of General Ecology. USA: WMC Brown. Company Publisher, 1976.

[24] M. G. Barbour, J. H. Burk, and W. D. Pitts, Terrestrial Plant Ecology. California: The Benjamin/Cummings Publishing Co., Inc., 1987.

[25] D. Mueller-Dombois and H. Ellenberg, Aims and Methods of Vegetation Ecology. Sanfransisco: W. H. Freeman and Company, 1974.

[26] N. Polunin, Pengantar Geografi Tumbuhan dan Beberapa Ilmu Serumpun, Terjemahan Gembong Tjitrosoepomo. Yogyakarta: Gajah Mada University Press, 1990. 